\title{
The 1935 Portuguese reinforced concrete code: Background, sources and authors
}

\author{
J.P. Delgado \& R.J.G. Ramos \\ University of Porto Faculty of Architecture (FAUP) and CEAU-FAUP, Centre for Studies in Architecture and \\ Urbanism, Porto, Portugal \\ P. Tormenta Pinto \\ Instituto Universitário de Lisboa (ISCTE-IUL) and DINAMIA-CET/IUL, Lisbon, Portugal
}

\begin{abstract}
The object of the paper is the 1935 Portuguese Reinforced Concrete Code (RBA), approved two years after the establishment of the Estado Novo regime. The research takes this background as relevant, as the code was a foundation for a programme of public works. The starting point is the report that prefaces the regulations. It clarifies the methodology adopted for defining design standards, which was to compare 14 of the most advanced regulations. The technical report also identifies all of the authors of the RBA, who were six leading structural engineers. The paper aims at a threefold relevance. Firstly, to understand the method used for drafting the code, and, consequently, to comprehend the dissemination of reinforced concrete. Secondly, to throw light on how the issues of development were addressed in the 1930s. And thirdly, to understand how European countries dealt with building modernization during that years.
\end{abstract}

\section{INTRODUCTION: OBJECTS AND AIMS}

The object of this paper is the Regulamento de Betão Armado (the Reinforced Concrete Code or RBA) the 1935 Portuguese code that laid out the technical standards for reinforced concrete (RC) study and design. Having remained in force until 1967, the code was approved on 15 October 1935 by the then minister of Public Works, the renowned engineer Duarte Pacheco (1900-1943). This ratification took place just two years after the establishment of Estado Novo, the nationalist authoritarian regime headed by Oliveira Salazar (1889-1970). The research undertaken proceeded from the belief that these historical facts are an important background, as the code was used as one of the main technical foundations for a vast programme of public works, including some important architectural and engineering assignments. Salazar and Pacheco conceived this plan as a response to the Great Depression, aimed at building much needed infrastructure in Portugal, and also at reducing unemployment and minimizing social unrest.

The paper's starting point is the comprehensive RBA technical report that prefaces the text of the regulations themselves. The report clarifies a number of aspects of the methodology adopted for defining the design standards, which was to look at and compare the most advanced regulations of the time, regardless of their geographic origins or political context. In an unbiased and open-minded way, the committee in charge of drafting the code compared 14 codes from different countries. The technical report also identifies all of the authors of the RBA, who were six leading structural engineers. A brief glance at their biographies reveals that they could all in some way be linked with the conservative traditionalist regime of the day. They were also involved in some most important engineering undertakings of the time. This situation raises several important questions, both regarding the committee and the code itself. With regard to the committee, the main doubts have to do with how its members were selected. As for the code, the questions centre on the drafting methodology, in particular that used for comparing foreign codes. Finding an answer to these questions may have a threefold significance. Firstly, in very specific terms, it may allow one to understand the method used for drafting the RBA code, and, consequently, to comprehend the dissemination 
of RC construction technology in Portugal. Secondly, in more general terms, it may help to throw some light on the ways the Estado Novo regime addressed the issues of technological development in the 1930s, particularly those related with the material progress of the country. And thirdly, for a broader audience, it may help to understand how peripheral European countries dealt with the challenges of building modernization during the interwar years. This contribution is relevant, if one keeps in mind that in Spain, a country with some similarities with Portugal, the first RC code was published only in 1939 (Peña Bœuf 1940). This paper sets out to answer the above-mentioned questions by presenting the results of ongoing research (Delgado 2014, Delgado \& Tormenta 2016) which is based on the existing biographical documentation on the committee members, on the one hand, and on archives and libraries dedicated to Portuguese public works, on the other.

\section{THE ESTADO NOVO REGIME: NATIONALISM, PUBLIC WORKS AND RBA}

The Estado Novo regime was in power in Portugal from 1933 until 1974, and was the further development of a 1926 military coup d'état that was carried out in order to install a right-wing dictatorship. As most researchers find it difficult to frame this regime in terms of its actual ideology, we have adopted the characterization given by the Portuguese historian Oliveira (1992). In his view, the dictatorship can be summarized by one main concept, i.e. nationalism, supporting three main pillars: authoritarianism, corporatism and colonialism. Salazar continuously endeavored to find a legitimacy that would sustain and justify himself, both internally and internationally. In part, he achieved this by means of the idea of nation, which was figured as a major device for the moral and social validation of the regime's political doctrine and its legal and institutional structure. Thanks to nationalism, Portugal was portrayed as the result of a long-lasting agreement between generations, ethnicities and classes, and this portrayal was meant to provide a cohesive system of both representation and symbolic expression. Nationalism was thus used as a political, social, and cultural tool. As it happens, in the 1930s the most straightforward and tangible historical rendition of Portuguese nationhood could be amply provided by the built heritage. Historic buildings - even those that were rebuilt or otherwise adulterated - were ready to serve nationalism and its perception of reality. It is in the light of this notion that we should look at one of the first acts of the Estado Novo regime, i.e., the national monument recovery programme. The programme encompassed the traditionalist, although at times fanciful, restoration of several historic buildings (Nunes 2008). This fervour also transferred to a public works programme gradually, but swiftly, throughout the 1930s (Saraiva 2016). Before this could happen, in order to ensure feasibility and safety standards, the regime soon realized that construction activities would have to be regulated (Delgado \& Tormenta, 2016).

The need for regulation resulted in the emergence of the RBA code, in itself a by-product of the Economic Reconstitution Act of 1935. To back this statement up, and to give a rough account of the key plans and projects that the Government intended to run in the following fifteen years, one can quote directly from the Act (Lei n. ${ }^{\circ}$ 1914/35 de 24 de Maio, 731): (i) completion of both railway network and road network; (ii) airports; (iii) commercial and fishing harbours; (iii) telegraph and telephone networks; (iv) nationwide electric grid; (v) agricultural hydraulics, irrigation, and settlement of inland; (vi) schools and other State facilities; (vii) special repairs of national monuments; (viii) Lisbon and Porto development works; (ix) loans to overseas colonies; (x) other undertakings that could be of direct interest, given the goals of this law. It is easy to understand that the regime intended to achieve economic recovery through a State-driven stimulus that was nothing else than a vast public works programme. Hence, the regime was planning to intervene in the Portuguese economy in two concurring ways. Directly, it sought to increase opportunities in all areas that depended on the construction sector. Indirectly, it aimed to boost the Portuguese internal market, as it was severely hampered by the deficiency of electrical and telecommunications facilities, and especially by the infrastructural lack of roads, railways, harbours and airports (Nunes 2008). However, as in other countries, the main political goal of this State intervention was to head off foreseeable social tensions that stemmed mainly from unemployment. The public works programme was carried out at different territorial levels - national, regional, and local, but, regardless of the scale of the interventions, the programme always involved the construction of buildings. What has to be stressed here is that this policy was largely supported by the RBA code. Some main achievements were the dams built in the 1940s for agricultural and electrical purposes. 

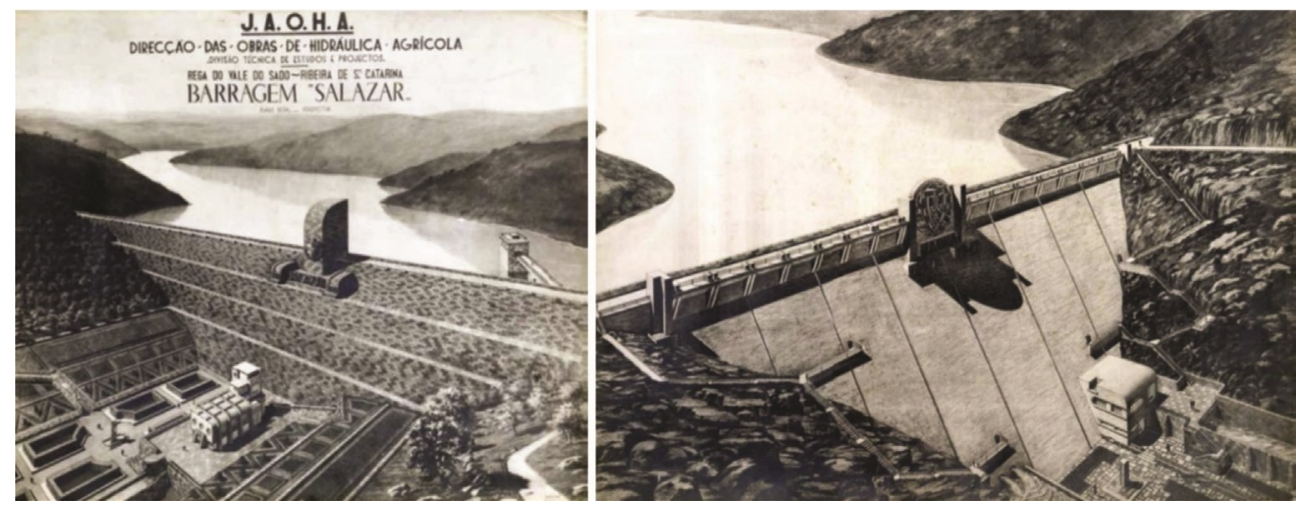

Figure 1. The "Salazar Dam", Ribeira de Santa Catarina, 1936-1949 (left), and the "Carmona Dam", Ponsul, 1936-1946 (right). Architectural design by Cassiano Branco (1897-1970). Source: The Cassiano Branco Estate, Lisbon Municipal Archive / PT/AMLSB/CB / 07/07/03 and / PT/AMLSB/CB/07/09/03.

\section{THE RBA CODE}

\subsection{Background, type, and structure}

Dealing mostly with in situ work, RBA was not the first code to regulate the use of RC in Portugal. It revoked Decree 4036 of 18 March 1918, which had originally approved the so-called "regulatory instructions for the use of RC". In the period of some 17 years that separated them, RC technology and construction processes evolved considerably. RBA presented a summary of the factors that had made the legal revision urgent. In short, the changes were the following (p. 1493): improvement in the collaboration between building sites and engineering laboratories; improvement in cement quality; development of new types of concrete, such as rapid curing concrete and high strength concrete; advancement in awareness of the relationships between concrete compositions and their physical properties; innovation in the strength of materials theory; and evolution of ferrous metallurgy, and the resulting improvements in steel.

Early regulations and guidelines on RC in Europe had important differences (Caminade 1935), namely in terms of impact, as they could be: national or regional based; meant for public or private construction; mandatory or simply advisory (Van de Voorde et al. 2017). The RBA was a national regulation; it was mandatory; it was meant for every building in Portugal, either public or private; and it was a code of standards enforceable by law, by means of Decree 25948. As in many countries, laws only became binding in Portugal after their publication in the official gazette, then called Diário do Govêrno. The RBA code was published on 16 October 1935, in the 1st Series of the gazette, which was reserved for important texts, such as laws. The decree was made up of three parts. Part one (p. 1493) was the preamble, which in a few paragraphs outlined the code philosophy, and justified the need for Government intervention in its drafting. Dated 16 March 1935, the preamble was signed by the President of the Republic, Óscar Carmona (1869-1951), by the Head of Government or Prime Minister, Salazar, and by the Minister of Public Works and Communications, Duarte Pacheco. Part two (pp. 1493-1505) is the report, which provided comprehensive reasoning for all the code's major decisions. This was signed by the committee members, and was dated 20 February 1935. Part three (pp. 1506-1522) was the full text of the code itself. As with most early national RC codes (Addis 2007, 464), this part gathered together three types of information: (i) on the properties of $\mathrm{RC}$ constituent ingredients and materials, and the manufacturing quality (pp.1507-1508); (ii) on the various loads that RC structures and elements should be designed to carry (pp. 1508-1509); and (iii) general standards of analysis (pp. 1510-1511), and standards of design practice for various RC structural elements, namely floors (pp. 1511-1513), beams (pp.15131514) and columns (pp.1514-1515). Special elements in different constructions were dealt with specifically, with a separation between buildings (pp. 1515-1517) and bridges (pp. 1517-1519). 
In addition to this information, the code set out detailed standards for the elaboration of the actual building process (pp. 1519-1521). All RC construction stages were taken into account: formwork; the arrangement and spacing of reinforcement rods; the preparation, placing and compacting of concrete; the construction joints between older and fresh pours; stripping of formwork; and curing. A final chapter was dedicated to RC building supervision (pp. 1521-1522). Pursuant to the code, RC building works were to be supervized as they proceeded, and this activity was to be carried out by appointed structural engineers, acting as officers designated by local governments or by the Ministry of Public Works and Communications).

\subsection{State of the art}

A characterization of RC state of the art in the 1930s is now essential, if one is to understand its importance to Portuguese engineering of the period. To this end, one requires a very brief discussion of the nature of RC structural analysis and design as it was understood in the early decades of the 20th century. As corroborated by various authors, particularly Viseu (1993), one can begin by stating that first years of use of RC were marked by a historical coincidence, i.e., the fact that this system evolved throughout the 19th century at about the same time that a specific branch of physics was evolving, i.e., Strength of Materials, or SoM. Since its inception, SoM was recognized as a suitable discipline for the structural analysis of buildings. Indeed, through study of the interaction between externally applied loads and their internal effects on a given body, SoM enabled the calculation of both deformation and strength. For this calculation to be possible, certain conditions must be given, relating to both the nature of the problems and the characteristics of the bodies. In short, the latter should be: elastic, returning to their original shape after being subject to tension; linear, with deformations proportional to stresses; homogeneous, with the same features throughout their mass; and isotropic, with equal properties in all their directions.

Elasticity, continuity, homogeneity, and isotropy allow for the application of a finite set of rules: Hooke's Law of linear elasticity; the Bernoulli-Navier Hypothesis, or the assumption of conservation of plane normal cross sections; and the Saint-Venant Principle of proportionality of tension in any given point of a section to its distance from the neutral axis. The simple content of SoM rules is enough to show their unsuitability for the analysis of certain structural materials. All the more certainly, the same should happen with RC. As RC is a composite system resulting from the combination of two very different materials, concrete and steel, it is by nature heterogeneous and anisotropic. However, for lack of a better scientific basis, SoM laws were widely used for RC structural analysis, from the beginning of the 20th century onwards for some decades to come. This calculation was made in conditions that were fixed by direct observation, by laboratory experiments, and by theoretical models, both graphical and analytical (Viseu 40). As can be easily inferred, most building codes concentrated on setting these conditions. The 1906 French regula-tions, published in the 'Circulaire ministérielle du 20 octobre 1906 relative aux ouvrages en béton armé' (Ministerial Circular of 20 October 1906 on Reinforced Concrete Works) pioneered this approach. The RBA was also necessarily devoted to this task. Its authors explained (p. 1496):

Reinforced concrete is a heterogeneous body. In order to allow for the application of Strength of Materials standards to constructions using it, we resort to turning reinforced concrete into a homogeneous material that is wholly equal from the mechanics point of view. This is done by amplifying the metal cross sections, multiplying them by a coefficient $m$, which should represent the ratio between the coefficients of elasticity of both constituents, provided that we do not take into account the modification resulting from the deformation of the stressed concrete.

Using the coefficient of equivalence ' $\mathrm{m}$ ' guaranteed the possibility of applying SoM principles (p. cit.):

When the elastic limit is not exceeded, the proportionality between deformations and stresses (Hooke's law) is assumed, as is the Bernoulli hypothesis regarding the conservation of flat sections and the consequent Navier law on proportionality between deformations and distances from the neutral axis.

This type of structural analysis was known as the elastic approach. More recently it has been renamed the classical method, as opposed to more recent approaches (Viseu 1993), such as those used in the 1967 code that replaced RBA. 


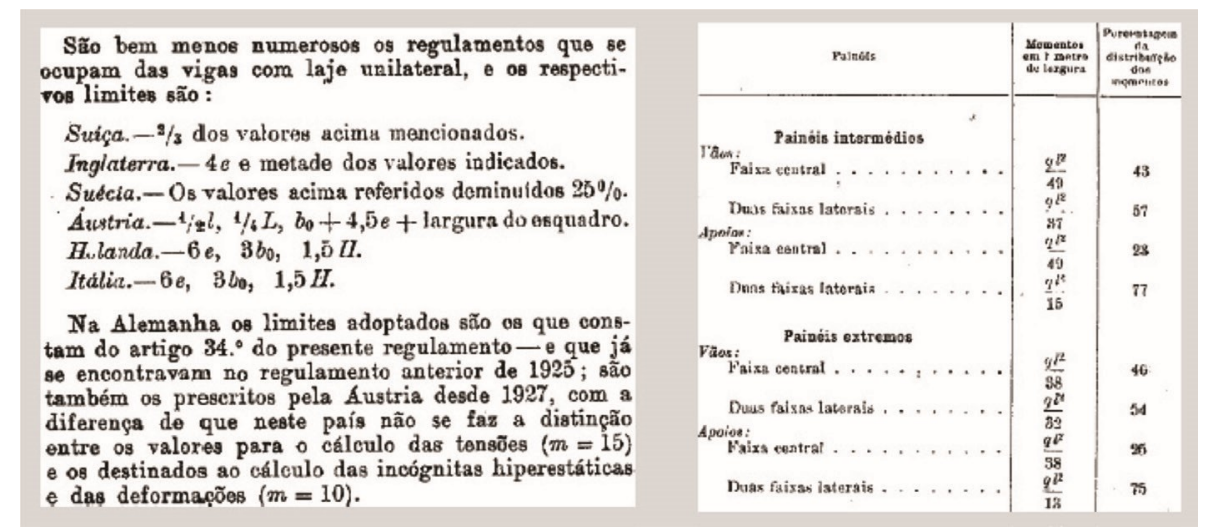

Figure 2. Two typical excerpts from the RBA code report. Comparing values for perimeter beams in Switzerland, England, Sweden, Austria, Holland, Italy, and Germany (left); and presenting a table with the case of flat slabs in the USA (right) (pp. 1503-1504).

\subsection{Benchmarking}

The short discussion of the type of structural analysis proposed by the RBA code had one single goal, which is to establish and emphasize two important ideas: (i) in the 1930s, a high degree of uncertainty was inherent in the application of classical structural analysis methods; and, for that reason, (ii) a RC building code could not be imposed responsibly without a firm grounding in the most accurate laboratory tests and in the most advanced theoretical models. It is obvious today, as it was then, that this task should only be assigned to highly specialized bodies. The report (p. 1494) considered that "this time-consuming and expensive work [...] can only be carried out by permanent study committees, such as those that happen to exist in other countries". In the absence of such a body in Portugal, and taking into account that the drafting committee had opted for a type of regulation that went beyond providing general information, indeed aiming higher, i.e., at stipulating "precise details regarding structural analysis principles, materials and their use" (p. 1493), the solution was to reach out to other codes, in search of notions, concepts, and values suited to the Portuguese case (p. 1495).

Any revision must be grounded in tests, experiments and observations, which require not only time, but also special laboratories and numerous building works, both completed and in progress; otherwise there is only one sensible secure way to proceed, and this is to make good use of the experiences of others.

In different degrees of extent and depth, the committee compared three values: (i) the coefficient of equivalence 'm'; (ii) compressive fatigue limit and bending fatigue limit; and (iii) shear stress. Apart from these analysis patterns, the committee used the same comparative and comprehensive methodology to propose rules and references for diverse constructive solutions which, due to their design complexity, where hitherto seldom used, not only in Portugal, but also in Europe. This was the case for two-way slabs (p. 1502), and waffle slabs (p. 1503). As far as resorting to other experiences is concerned, the report singles two countries, which were the United States and Germany, and also listed the reasons for that choice (p. 1493): population and culture; "outstanding development" in terms of RC building works; and great amount of theoretical studies, experimental research, and publications on RC structures. In addition to these two countries, the report credited, in great detail, the codes that served as comparisons for the drafting of RBA code. We list them here, respecting both the alphabetical order and the onomastics used in the report: Austria; Belgium; Czecho-Slovakia; Denmark; England; France; Holland; Hungary; Italy; Russia; Sweden; and Switzerland. In short, an impressive number of 14 different codes were assessed.

Shortly after publication of RBA, however, some experts pointed to the German RC regulation of 1932 as the main reference for the Portuguese version. This was the case of the civil engineer Virgílio de Lemos (1936), who referred to the similarities between the two texts as "extraordinary affinities". 
In the same article, Lemos also provided valuable indications with regard to the ease of access to the German regulations. First of all, he pointed out the existence of a translation into Portuguese (Junqueira 1933), published by the Brazilian magazine "Boletim do Instituto de Engenharia", and that said magazine was indeed available in the library of the Association of Portuguese Engineers for easy consultation by its members. Research conducted in Portuguese engineering journals of the time reveals that that institution was not the only one to receive the Brazilian publication. Thus, for example, the magazine published by the Student Association at Instituto Superior Técnico, the reputed school of engineering in Lisbon, indicated it as available in its collections, this presenting us helpful insight into how technical information circulated around the globe in the 1930 s.

\section{THE RBA DRAFTING COMMITTEE}

The detail and the depth of the report reveal the know-how of the committee members. Since the document was signed by all of them, verification of their capabilities is an easy task today. They were the following: Manuel Pereira Viana, João Barbosa Carmona, Augusto Vieira da Silva, António Maria Fernandes, José Bélard da Fonseca and Raul Jales Guimarãis. Their names give rise to a number of questions. Who were these engineers? What particular skills did they possess? What contributions did they make to the obvious assuredness that both the text of the code and its preliminary report reveal? What information can one gather from their careers, regarding both the RBA philosophy and the period in which it was written? With a view to finding answers to these questions, the following paragraphs reflect on what one can uncover from their biographies.

For Manuel Pereira Viana it was not possible to confirm the date or place of birth, which is surprising, given his academic and political career. It is known that he was an officer of the Portuguese Navy, having completed considerable technical training, as he was both a graduate in Mathematics from the University of Coimbra and in Civil Engineering from the French École Nationale des Ponts et Chaussées. It is also known that between May and December 1909 Viana was Minister for the Navy and for Overseas Territories. He received this post in the penultimate government under the constitutional monarchy. Opponents of this particular administration referred to it pejoratively as the Porto Polytechnic Executive (CEPP 2003). Indeed, like some of his fellow ministers, Viana had been professor at the Porto Polytechnic, first as chair of Hydraulics and Machinery and later, from 1889 on, of Strength of Materials and Construction Stability (Delgado \& Tormenta 2016). As we saw above, having a sound knowledge on SoM was essential for the calculation of RC structures. His knowledge in this particular field may have been the reason Viana was considered to have both the education and the recognition to be a member of the commission. His position as first signatory may also indicate that was its chairman.

João Alberto Barbosa Carmona (1894-1958) had a degree in Civil Engineering from Instituto Superior Técnico. He had been an artillery officer, having graduated from the Portuguese Military Academy. He remained in the Portuguese Army until 1929, reaching the rank of major. At the time of the drafting of the new code he was the Bridge Department Director at Junta Autónoma de Estradas, the Portuguese Roads Authority, having led the construction or renovation of some three hundred bridges across the country (Delgado \& Tormenta 2016). This expertise explains why he was part of the drafting committee.

Augusto Vieira da Silva (1869-1951) is the name that most resonates for the Portuguese lay public, as he is relatively well known as a Lisbon historiographer. In addition to this activity, he was also a military engineer, having graduated from the Military Academy in 1893. He retired from the armed forces in 1936 with the rank of colonel (Delgado \& Tormenta 2016). Not unusually for the times, Vieira da Silva also had a career as civil servant. For example, it was as an officer of the Direcção Geral do Trabalho - the Portuguese Directorate-General for Labour - where he worked from 1922 on, that he undertook the structural analysis for the reconstruction of a previously burnt-down building at Praça do Comércio, in Lisbon. From as early as 1913, he authored several papers on RC structural analysis and design. It is likely that Vieira da Silva contributed to the code as the government's Industrial Engineering Inspector, an office he held from 1925 onwards (Delgado \& Tormenta 2016).

In contrast to the wealth of information available on almost all other members of the commission, very little is known about António Maria Fernandes (1892-?). The Ministry of Public Works 
records (BAHOP 2011) reveal that between 1920 and 1934 Fernandes was a civil engineer at the Direcção Geral de Edifícios e Monumentos Nacionais (Directorate-General for National Buildings and Monuments). It is also known that in 1946 he would become director of Laboratório de Ensaios e Estudo de Materiais (Laboratory for Testing and Study of Materials) (LNEC 2012). This fact seems to attest to Fernandes' suitability to be a member of the drafting committee.

José de Mascarenhas Pedroso Bélard da Fonseca (1899-1969) was also an Instituto Superior Técnico Civil Engineering graduate. He was a professor at that same school, and was to become its Dean in 1942. He remained in that office until 1958, when he was appointed Vice-Chancellor of the Technical University of Lisbon. Bélard also took on corporate duties, namely as chairman of the board of SECIL (Castilho et al. s.d.). SECIL, a company founded in 1930, is to this day one of Portugal's leading cement producers. Bélard was concurrently head of SETH, a building company which, after being set up in 1933 by the Danish firm Højgaard \& Schultz a/s, immediately received major public works commissions (Delgado \& Tormenta 2016). These included several important bridges and dams, and also the port of Funchal, Madeira. As a structural designer, up to the date of the RC code, Bélard da Fonseca had already contributed to some emblematic buildings from the most representative Portuguese architects. One major example of such architects was Porfirio Pardal Monteiro (1897-1957), with whom Bélard teamed up to analyse several RC structures for iconic buildings in Lisbon, such as the National Institute of Statistics in 1931 and the Church of Our Lady of Fatima in 1933 (Delgado \& Tormenta 2016). Another architect was Cristino da Silva (1896-1976), with whom Bélard designed the Capitólio Theatre in 1925 (Rodolfo 2002). Besides his various teaching, business, and design undertakings, Bélard also was intensively active politically, namely in the area of representation of associations. Between 1935 and 1938, during the First Legislature of the Estado Novo regime, he was a delegate to the Corporative Chamber in the Portuguese Parliament, where he was returned for a second term of office, this time as a building companies' representative. Later, from March 1947 to February 1950, Bélard was to take a seat in the same chamber (Castilho et al. s/d), as President of Portuguese Association of Engineers. This impressive résumé fully explains Bélard appointment.

An academic publication (Universidade do Porto, 1915) establishes that Raúl Jales de Guimarãis (1894-?) attended the University of Porto School of Sciences in the academic years 1911-1912 and 19131914. Shortly after graduating in Civil Engineering, he became a civil servant in 1919, serving as a design specialist at the national railways company (Delgado \& Tormenta 2016). For a short period of time, Jales de Guimarãis was the Chief of Staff at the Ministry of Trade and Communications. He took that office in 1925, a few months before the May 1926 upheaval that led to the Estado Novo regime. This did not prevent him from accepting, in 1930, a function at a commission for the certification of bridge structures. It was probably his membership of that body that qualified him to be a member of the committee. Shortly after publication of the RBA Jales de Guimarãis became executive officer of Junta Autónoma de Estradas. In 1939, he was also appointed by the Lisbon City Council to oversee all engineering works required for the conversion of the Monsanto hill into a large forest park (Delgado \& Tormenta 2016).

\section{CONCLUSIONS}

The conclusions concerning the establishment of RBA code are presented below, along with some of the cultural and ideological aspects that we have identified before: (i) the RBA code merged all regulatory developments of the most advanced countries, especially Germany, based both on their laboratory tests and on the best practices at that time; (ii) this commitment to assessing foreign experiences was not only clearly identified in the report, but was also deemed as suitable, appropriate and advisable; and (iii) the report contained nothing that indicated a desire or a need to impose a Portuguese way to solve the problems inherent to RC technology. Having presented an overview of the engineers, we can establish three answers to our questions: (i) The content of each biography would seem to indicate that all six were part of a technocratic élite of the Estado Novo regime, which was made up of those who had achieved renown in their respective fields and also had a certain affinity to the regime with regard to the ideological sensibilities of the ruling power. (ii) It seems clear that an eclectic, pragmatic spirit presided over the make-up of the RBA committee. Its members represented a wide spectrum of the Portuguese engineering profession and knowledge, incorporating much of the then current RC 
understanding and application and taking many of the different perspectives regarding the subject into account. (iii) Despite having only six members, the committee brought together several latent professional dichotomies: between the military and the civilians; between scholars and practitioners; between those educated in Lisbon and those in Porto; between designers and entrepreneurs; between self-employed professionals and civil servants; between those experienced in private and those in public works; between those who built bridges and those who designed buildings.

Some of these dualities related to the engineering profession in particular, but also to Portuguese society in general: between the old and the younger; between monarchists and republicans; between those associated with the regime and those who were relatively neutral. In short: all these different groups seem to have been represented by a member of the committee. The breadth of this sociological and political variety indicates that the consensus concerning the widespread use of RC structures in construction works was, in the 1930s, very much unchallenged within the Portuguese élite and the political regime. It should be noted that the agreement that was established in relation to this technology seems to have been relatively neutral with respect to the cultural and ideological differences advocated by the various factions supporting the regime. If one accepts that all those factions were subjugated, in one form or another, to the idea of nation, one can assume, with a high degree of certainty, that the guardians of the nationalistic systems of representation and symbolic expression of the State did not feel particularly threatened by the widespread use of RC. In turn, it is this pervasive unanimity that may explain the strength and coherence of the RBA. Despite their differences, the committee's engineers were able to produce a document that was so articulate that it was only replaced in 1967.

\section{FUNDING}

J. P. Delgado is beneficiary of a post-doctoral grant by FCT, reference SFRH/BPD/118681/2016.

\section{REFERENCES}

Addis, B. 2007. Building: 3000 years of design engineering and construction. London: Phaidon. BAHOP. 2011. "Fernandes, António Maria - Processo individual”. BAHOP - Digitarq. [Online].

Caminade, H. 1935. Les prescriptions officielles et règlements pour les constructions en béton armé. Travaux 19 (36): 435-439.

Castilho, J. M. Tavares \& AR. “Os Procuradores da Câmara Corporativa (1935-1974)”. AR. [Online].

CEPP. 2003. “Governo de Wensceslau de Lima - 1909”. Repertório Port. de C. Política - CEPP. [Online].

Dec. N. ${ }^{\circ}$ 25948/35 de 16 de Outubro. 1935. Regulamento de Betão Armado. Diário do Govêrno (240/35).

Delgado, J. P. 2014. Uma concepção totalitária - Ars Arquitectos. Unp. PhD thesis. Lisboa: ISCTE/IUL.

Delgado, J. P. \& Tormenta, P. 2016. The 1935 'Regulamento de Betão Armado' building code: technological, ideological and cultural implications. In Póvoas, R. F. \& Mateus, J. M. (ed.). Culturas Partilhadas: Actas do II Cong. Int. História da Construção Luso-Brasileira, Porto, 14-16 Sep. Porto: CEAU.

Gonçalves, R. 1993. História da Arte em Portugal: de 1945 à actualidade. Lisboa: Verbo.

Junqueira, J. 1933. Normas da comissão allemã de concreto armado. Boletim do Instituto de Engenharia (90): 315-318; (92): 95-103; (97): 354-359; (102): 297-304.

Lei n. ${ }^{\circ} 1914 / 35$ de 24 de Maio. 1935. Diário do Govêrno n. ${ }^{\circ}$ 118/35 - I Série. Lisboa: Pres. Conselho.

LNEC. 2012. "Dep. de Materiais História”. LNEC [Online].

Lemos, V. 1936. Observações ao Regulamento de Betom Armado. Revista da AECP (736): 383-391.

Nunes, T. 2008. A década de ouro das obras públicas. In Paço, A. (ed.), Os anos de Salazar. s/1: PDA. 5.

Oliveira, C. 1992. Da construção do Estado Novo à Segunda Guerra Mundial. In Joel Serrão \& A. H. Oliveira Marques (ed.), Nova História de Portugal. Lisboa: Editorial Presença. Vols. XII.

Peña Bœuf, A. 1940. Hormigón armado. Madrid: Herrera

Rodolfo, J. 2002. Luís Cristino da Silva e a arquitectura moderna em Portugal. Lisboa: Dom Quixote.

Saraiva, T. 2016. Fascist modernist landscapes: wheat, dams, forests, and the making of the Portuguese New State. Environmental History 21(1): 54-75.

Van de Voorde, S., Kuban, S. \& Yeomans, D. 2017. Early regulations and guidelines on reinforced concrete in Europe (1900-1950). Towards an international comparison. In Campbell; J.; Baker, N; Driver, M.; Heaton, M.; Pan, Y.; Rosoman, T.; Yeomans, D. (ed.), Building Histories; Proc. fourth conf. Construction History Society. Cambridge: Construction History Society.

Viseu, J. 1993. História do betão armado em Portugal. Lisboa: ATIC. 


\section{Structures and Architecture}

The aim of the book series Structures and Architecture is to explore and to promote the merging of the fields of Structures and Architecture, encompassing all the aspects related with the recent advances in the art, practice and theory of teaching, researching, designing and building structures.

ISSN: 2643-6698

eISSN: $2643-6701$

1. Structures and Architecture - Bridging the Gap and Crossing Borders Edited by Paulo J.S. Cruz

ISBN: 978-1-138-03599-7 (Hbk + multimedia device)

ISBN: 978-1-315-22912-6 (eBook)

DOI: https://doi.org/10.1201/9781315229126 